\title{
Regulating Industrial Parks Development in Ethiopia: A Critical Analysis
}

\author{
Ermias Wedajo Azmach* \\ Licensed Trial \& Corporate Lawyer, Office of Attorney General, Hawassa, Ethiopia \\ Email: wodajolaws@gmail.com
}

How to cite this paper: Azmach, E. W. (2019). Regulating Industrial Parks Development in Ethiopia: A Critical Analysis. Beijing Law Review, 10, 23-60.

https://doi.org/ 10.4236/blr.2019.101003

Received: November 19, 2018

Accepted: January 15, 2019

Published: January 18, 2019

Copyright (๑) 2019 by author(s) and Scientific Research Publishing Inc. This work is licensed under the Creative Commons Attribution International License (CC BY 4.0).

http://creativecommons.org/licenses/by/4.0/ Open Access

\begin{abstract}
There is strong policy and legislative rationales behind establishing Industrial Parks. International experience has shown that successful IP have clear rules on regulatory objectives, location decisions, investor selection and land acquisition procedures. Perhaps most importantly, the global experience of IP's suggests that optimal results are achieved when they are established and operated as part of a national economic development regulatory reform strategy, and not as a "one off" venture. This paper is intended to provide a brief overview of the regulatory areas and instruments of IP's, the different experiences, the key lessons that Ethiopia can learn from other countries, as well as the recent evolution of regulatory areas in the world. Some key elements for success are provided specifically on those critical regulatory areas and instruments of location decisions, regulatory objectives, investor selection and land acquisition procedures as well. The adequacy and potential of the legal frameworks to respond to these regulatory areas are inspected. This article presents the main findings with respect to the four currently operational zones: development goals and the anticipated regulation of the zone projects, key regulatory challenges and preliminary proposals on enhancing the regulatory process. Hence, the study identified the inadequacy of legal frameworks on location decisions with a less concentrated regulatory objective and blurred rules on investor selection and land acquisition procedures. The existing rules do not establish well-empowered, central and effective regulatory organ in regulating and handling industrial disputes and grievance of industrial park investors. Most importantly, the finding shows IP rules fail to embody local content, backward and forward linkage with local entrepreneurs, investors and producers which have emanated from absence of a prior well-developed coherent IP policy.
\end{abstract}

${ }^{*}$ LLB (Haramaya University), LLM in Commercial laws (Hawassa University) and former Corruption Prosecutor@ Ethics and Anti corruption Commission. 


\section{Keywords}

Industrial Parks, Special Economic Zones, Free Zones, Empirical Evidences, Regulatory Areas, Regulatory Objectives, Regulatory Instruments

\section{Introduction}

The term "industrial park", which is used interchangeably with the term "special economic zones", encompasses a number of interrelated concepts, including Free trade zones, Free ports, Foreign trade zones, Export processing zones, Trade and economic cooperation zones, Economic processing zones and Free trade zones. There is multiplicity of names and forms of economic zones and definition vary across countries and institutions. Some countries made it purely a legal space sufficiently precise to exclude those that do not display the essential structural features that make it a zone (FIAS, 2008). But despite the many variations in name and form, all IP's can be broadly defined as-

"demarcated geographic areas contained within country's national boundaries where the rules of business are different from those that prevail in the national territory. These differential rules principally deal with investment conditions, international trade and customs, taxation, and the regulatory environment; whereby the zone is given a business environment that is intended to be more liberal from a policy perspective and more effective from an administrative perspective than that of the national territory." (FIAS, 2008)

In this paper, "industrial park" will be used in its most general sense, i.e., involving the provision of common infrastructure to a group of industrial firms in a demarcated area with additional or special regulatory areas and instruments. Other definitions exist, some of them for specific legal and technical reasons. For instance, the Revised Kyoto Convention of the World Customs Organization defines free zones as "a part of the territory of a Contracting Party where any goods introduced are generally regarded, insofar as import duties and taxes are concerned, as being outside the customs territory" (cited by Creskoff and Walkenhorst, 2009). The first issue that demands special consideration in this respect is the legal foundation underlying their establishment. Generally, industrial parks are defined as industrial enclaves that enjoy certain preferential policies for "export oriented manufacturing". However, overtime the model has evolved in terms of objectives, preferential policies, governance, ownership and location (Kaplinsky, 1993). According to Kaplinsky, the rationale for industrial parks establishment has traditionally been twofold. First, the provision of functional infrastructure is much easier to plan in a geographically limited space, particularly for delivery-constrained governments. Second, the concentration of firms can provide significant spillover effects both inside and outside the park: information spillovers, including knowledge and technology; the specialization and division of labor among enterprises; the development of skilled labor markets; and 
the development of markets around the parks.

Industrial Parks proclamation of Ethiopia (Industrial parks proclamation 886/2015) puts the following objectives of industrial parks establishment: 1) regulating the designation, development, and operation of industrial park; 2) contributing towards the development of the country's technological and industrial infrastructure; 3) encouraging private sector participation in manufacturing industries and related investments; 4) enhancing the competitiveness of the country's economic development; and 5) creating ample job opportunities, and achieving sustainable economic development.

Industrial parks have had a mixed record of success. Anecdotal evidence turns up many examples of investments in zone infrastructure resulting in "white elephants," or zones that largely have resulted in an industry taking advantage of tax breaks without producing substantial employment or export earnings (Warr 1989). Empirical research shows that many SEZs have been successful in generating exports and employment, and come out marginally positive in cost-benefit assessments (read Hamada 1974; Madani 1999; World Bank 1992, cf. Kaplinsky 1993, Johansson and Nilsson 1997; Willmore 1995, Farole 2011, p.23, FIAS, 2008). A number of examples, however, also illustrate the catalystic role zones play in processes of economic growth and adjustment processes (For deep analysis of EPZs in East Asia and the Masan zone in Korea, read Balasubramanyam (1988), World Bank (1992) and Willmore (1995)). For example, many of the zones established in the 1970s and 1980s in East Asia's "tiger economies" were critical in facilitating their industrial development and upgrading processes. Similarly, the later adoption of the model by China, which launched IP's on a scale not seen previously, provided a platform for attracting FDI and not only supported the development of China's export oriented manufacturing sector, but also served as a catalyst for sweeping economic reforms that later were extended throughout the country. In Latin America, countries like the Dominican Republic, El Salvador, and Honduras used free zones to take advantage of preferential access to U.S. markets and have generated large-scale manufacturing sectors in economies that previously were reliant on agricultural commodities. In the Middle East and North Africa, IP's have played an important role in catalyzing export-oriented diversification in countries like the Arab Republic of Egypt, Morocco, and the United Arab Emirates. And in Sub-Saharan Africa, Mauritius is an example of zones operating as a central policy tool supporting a highly successful process of economic diversification and industrialization. (For further analysis of EPZs in Latin America, Africa and Asia see Teutli (1980), ILO/UNCTC (1988), Grunwald (1991), Kaplinsky (1993), Burns (1995), Mata (1995), Mortimore et al. (1995) and Willmore (1995)). New varieties of zones have evolved in the category of parks. FDRE government industrial parks proclamation encompasses different types, size and models of zones under the definition provided for "industrial parks" and qualify them for rights, duties and incentives (Industrial Parks proclamation No. 886/2015). The growing literatures on various aspects of industrial parks have found little consideration to the 
growing "concept" of Industrial parks regulatory realm. Hence, there is a need to assess the theoretical foundation to explain the rationale underlying their establishment and regulatory areas and instruments (Aggarwal, 2010). Therefore, the study sets out to address the conceptual realm about industrial parks regulation in selected countries and in Ethiopia in particular.

Industrial Parks development and operation requires four key players-developer, manager, operator and regulator (Little, 2014). If all of the key players fall in the hands of public sector, it creates a conflict of interest in which the government will be responsible for initiating, planning, developing, promoting, administering and operating all zones in a country including those developed and operated by the private sector. If the same government agencies are responsible for regulation and development, they are regulating themselves. It could be a significant barrier to attracting private sector developers especially when private developers run into disagreement with the regulator. Separating the regulatory role from the roles of owner, developer and operator allows the regulator to remain fully independent from any zone development (Jenkins, Mauricio; Gerardo Esquivel, \& Felipe Larrain B, 1998). Several factors are often posited to explain the failures of industrial parks programs. One of the most cited factors includes the absence of partial institutional regulatory forms called "role allocation" in park's implementation. The mixed models of steps in industrial park development from location selection up to monitoring \& evaluation stages' while the stakeholders' responsibility in each stage being taken into consideration (Kalansky, 1993). Hence, this paper assess the involvement and role assignment of industrial parks development in the country from location selection till operation and monitoring together with land allocation and investor selection process in light of well developed empirically developed theories \& experiences. Moreover, the regulatory authority is the most important institutional actor in any zone program. A variety of institutional arrangements have been adopted in many countries, including government authorities or corporations, department based in specific ministries, zone specific management boards and investment promotion agencies. Best practice is to establish regulator as an independent agency under a board of directors that includes both public and private sector members. These make up helps separate the zone regime from political processes. Ethiopia establishes Industrial Parks Development Corporation (IPDC) as a federal government public enterprise with a dual role of developer and regulator (Regulation No 326/2014). The establishment regulation provides that a body to be designated by the government shall be the supervising authority of the corporation. ${ }^{1}$ Hence it is vital to assess the governing entity model and the relationship between the four key players and specifically, the powers and institutional set up of the regulator, from empirical and theoretical foundations in light of well developed regimes to grasp well-fitted model for the country. Be-

${ }^{1}$ The establishment regulation under article 3 reads " a body to be designated by the government will be the supervising body" which is quite less clear what is the status of the body and when it will be established. 
sides Lesotho, many African countries have not developed zones with an explicit regional development agenda (Zeng, 2015). Yet, even in these countries, it is obvious that zones located in more peripheral regions are unlikely to be successful, particularly if they are not designed around specific sources of comparative advantage. ${ }^{2}$ The experiences outlines underscores the importance of having a clear and transparent set of criteria by which location decisions are made, and going through a proper process of feasibility assessment before moving forward with zone investments. This paper is an attempt to assess the criteria employed by the government in making location decisions in light of well-developed theories and regulatory success of selected countries from the world and specific to Africa.

For industrial parks development purpose, industrial parks proclamation 886/2015 under Article 2(8), defines "investment" as "expenditure of capital in cash or in kind or in both by industry park developer", industry park operator or industry park enterprise as the case may be, to establish a new or to expand or upgrade industrial park, industrial park operation and industrial park enterprise within the industry park in accordance with the permit issued or agreement concluded. The proclamation also defines, "Industrial Development Zone" as an area with distinct boundary designated by the appropriate organ to develop identical, similar and interrelated industries together or to develop multi-faceted industries based on a plan fulfilling infrastructures such as road, electric power and water and having incentive schemes with purposes containing industrial development, mitigating the impacts of environmental pollution and administering the development of urban with plan land system; and defines "Industrial Park" as an area with distinct boundary designated by the appropriate organ to develop comprehensive, integrated, multiple or selected function of industries, based on planned fulfillment of infrastructure and various services such as road, electric power and water, one stop shop and have special incentive schemes, with a broad view to achieving planned and systematic, development of industries, mitigation of impacts of pollution on environment and human being and development of urban centers, and includes special economic zones, technology parks, export processing zones, agro-processing zones, free trade zones and the like designated by investment board; The proclamation obliges the federal government to establish industrial development zones in regions and industrial zone development shall be undertaken by the federal government or, where necessary, by joint investment of the government and private sector (Proclamation No. 886/2015; Article 2(1); 2(11); 33;35;37). Those matters concerning designation, allocation standard, boundary delimitation of industrial development zones, the rights and duties of investors engaged in, the services expected from the government and supervision thereon, completion of construction activities and supervision thereon, incentives other than those under the proclamation and the rules related to the implementation of industrial parks and the organ to engage in the federal government development activities of industrial develop${ }^{2}$ In some other cases-such as Mauritius, Honduras, and El Salvador-local investors played a critical role from the start, catalyzing Foreign Direct Investment (FDI). 
ment zone is established by regulation of the Council of Ministers (Regulation No.326/2014). In this research paper, as defined under Ethiopian law, "Industrial park" will be used in its most general sense, i.e., involving the provision of common infrastructure to a group of industrial firms in a demarcated area established to develop comprehensive, integrated, multiple or selected function of industries involving special regulatory areas and instruments. ${ }^{3}$

\section{Defining and Measuring Success of Industrial Parks}

Industrial parks are normally established to act as catalysts for trade, investment, and wider economic growth. Most often, they aim to improve competitiveness to facilitate the economic transformation of their host countries faster or more effectively than would be possible without them. In different countries and at different times, however, the specific objectives vary, from attracting FDI to creating employment to experimenting with reforms. These are all possible objectives by which to measure the success of zone programs. ${ }^{4}$ There are specific frameworks that draw on each of these principal objectives to assess zone outcomes. The distinction we make in our framework is between objectives whose outcomes are static in nature and those that are dynamic. We define static economic benefits as those derived in the relatively short term through the use of economic zones as instruments of trade and investment policy. These static benefits are the result of capturing the gains from specialization and exchange. They include employment creation; the attraction of foreign direct investment (FDI); the generation of foreign exchange through exports; and the creation of economic value added. Economic zone programs that are successful in contributing to long-term development leverage these static benefits into dynamic economic benefits, which include the promotion of nontraditional economic actors (Eifert, Gelb, \& Ramachandran, 2005).

More specifically, good practice IP's share the following key attributes: 1) Physical planning and infrastructure: -Integrated, multi-use development, Effective IT systems and networks, availability of specialized facilities and business service, Public provision of off-site infrastructure; 2) Development Approach: -Business driven (demand driven as opposed to policy driven); Part of a national economic growth strategies; Public-private partnerships or private developer builds/owns/operates; Industrial Parks on cost-recovery basis 3) Policy Features: Political consensus - political "champions" to support required reforms; Best practice regulatory framework and stable business environment; Targeted at ${ }^{3}$ Recall that an assumption and the reality in the ground in this analysis is that all firms in Ethiopian Industrial Parks are foreign-owned. The experience taken and comparison is also made from those countries that initiated Industrial Parks development mainly to attract foreign capital and successfully link the foreign investors and investment with the local or national economy (local content, backward linkage, forward linkage).

${ }^{4}$ Some IP's, normally traditional IP's, target foreign investors explicitly by setting the eligibility criteria of foreign capital. Others do not limit the zones to foreign investors, but other eligibility criterion often becomes too high a hurdle for domestic investors, especially those with limited capital. More recently established zones, particularly those under the more modern SEZ models, encourage domestic as well as foreign investment. 
multi-markets and not just for exports ;Wide range of activities permitted; Emphasis on deregulation and de-monopolization; Streamlined procedures to establish and operate enterprises; Shift towards universal tax incentives/low tax area; Adherence to universal labor rights; Environmental compliance, equal treatment of all foreign and domestic companies; incentives for private developers; and 4) Institutional Framework: -establishment of a single administration to manage zone activities and high level political support, one-stop shop for efficient zone regime regulation, Autonomous, flexible, well-funded regulatory authority (Farole, 2010).

\subsection{Key Success Factors: Empirical Evidences}

The following countries have been scientifically proved to be successful through employing critical legislative measures in facilitating: 1) forward and backward linkage 2) linkage between foreign and domestic investors investment inside the park 3) very clear and specific regulatory objectives and instruments 4) the critical role played by the industrial park authority in fulfilling the critical needs of investors and facilitating technology transfer, skilled labor and consultancy services. While other factors remain constant, most importantly, these countries are selected for this research based on scientifically proven success factors in their overall economic reform and legislative framework.

Bangladesh-Terms of forward linkages, the industrial parks program has restrictive policies in place, limiting local market sales to only 10 percent of production. Most important, for textiles and garment companies, who make up the bulk of export industrial parks enterprises, no local sales are allowed. The local market restriction attempts to protect against unfair competition, which is understandable given the size of the local industry and the substantial incentives available to park-based companies. Backward linkages, however, are not actively prohibited and, in theory, are encouraged. However, a number of regulatory, administrative, and general market factors place significant barriers in the way of backward linkages. In theory, local producers selling into the industrial parks can obtain duty drawback on imported inputs (as an indirect exporter), putting them on a level playing field with foreign suppliers to the industrial parks. This certainly may be something that is not the case in many industrial parks programs in Africa, for example (Aggarwal, 2005).

Bangladesh Export Processing Zone Authority (BEPZA) offers the best service in terms of ease of obtaining licenses and approvals. BEPZA's recommendation to other agencies is taken seriously and BEPZA's officials make an effort to guide the processes through the various channels. The administrative functions within BEPZA's own domain work quite well and investors seem to be quite satisfied with the speed and efficiency of the system. The BEPZA executive board has the capacity to make its own decisions and execute them. Moreover, certain activities have authority delegated to BEPZA, including registering a business, foreign investments and loans approval, and outsourcing services such as power generation. The fact that BEPZA reports directly to the prime minister's office is seen 
as a critical factor that supports its efficient delivery of services to investors. BEPZA's role as regulator and operator has been identified as a major obstacle to the continued success of the zones, both in terms of regulatory compliance and private sector-led growth (Ganne \& Lecler, Y., eds. 2009). The act moves Bangladesh beyond the traditional IP regime to embrace a broader IP or "economic zone" model. Specifically, it allows for much larger scale zones and takes a more flexible approach to the types of activities that can be undertaken within the zones. In addition, not only does the new act put greater emphasis on private sector participation in zone development, but it also substantially alters the role of BEPZA by splitting its regulator function from its development and management role. Finally, it ensures more private provision of public goods in the zones as well as Public Private Partnerships (PPP). ${ }^{5}$ The Economic Zones Act, which was passed by Parliament in July 2010, has the following strategic provisions: 1) Establish one law to govern all economic zone programs in the country; 2) Create a broader and more flexible model for zones allowing exports as well as local sales; 3) Bring larger areas under special regimes, which may include existing IPs and industrial estates; 4) Set clear and objective criteria for site selection and mandatory feasibility studies to eliminate discretionary powers and erratic decision making; 5) Facilitate an increased role of the private sector in ownership, management, and operation of zones; 6) Allow a light-handed approach to the regulation of zones; 7) Ensure that all zones are operated on commercial principles and the market to drive the price of services, 8) Allow the conversion of any zone into an IP with parameters fulfilled. 9) Make a provision for declaring large geographic areas to be brought under special administrative and incentive regimes (World Bank, Doing Business 2010).

Honduras-Honduras has been fairly successful at developing backward linkages (i.e., establishing a domestic support industry that provides locally produced goods and services for the free zone-based manufacturers). Local suppliers based in Honduras now are providing a number of locally produced intermediary goods in the production chain, in particular, textiles used in the apparel sector. As of 2011, Honduras had 10 to 12 mills producing textiles for the clothing and apparel sectors (World Bank, Doing Business 2010). Most critical in this regard was the 1987 Export Processing Law, which: 1) abandoned the previous policy discriminating against domestic private investors, and 2) opened up the fiscal incentives of the free zone program to export-oriented companies and real estate developers who invested in the physical infrastructure of industrial parks anywhere in the country. Further development of the legal framework sought to create more backward linkages by extending many of the tax-free and duty-free incentives to local producers outside the free zones. The evolution culminated in 1998, with the declaration of the entire national territory as a Free Zone Area (Decree No. 131-98).

${ }^{5}$ BEPZA (Bangladesh Export Processing Zones Authority). 2009a. "Investment Opportunities in the EPZs of Bangladesh.” Presentation to the World Bank Group, Dhaka. 
From its inception, FIDE's objectives have been to promote investment, develop export markets, and work closely with the government and other private organizations to create new legislation aimed at improving the business climate in Honduras. A key initiative of FIDE was to establish export promotion offices in Florida, Atlanta, and New York to nurture networks and connect Honduran exporters and zone operators with companies in leading U.S. centers of textiles and clothing production. This policy was successful and much valued by Honduran-based companies that benefited from the contacts established by FIDE and the investment that was generated through its work. The domestic industry's investment in zone infrastructure and the establishment of manufacturing companies catalyzed FDI. ${ }^{6}$

The free zone industry now is almost entirely made up of private zone operators and private companies. Although domestic entrepreneurs have played an increasingly important role as investors in free zone companies-for example, between 2000 and 2007, Honduran companies in the free zones grew by almost 700 percent, or from 13 to 103 companies - it was the role of local industrialists in establishing the free zone industrial parks in the later 1980s and early 1990s that was critical to catalyzing FDI into the sector, which in turn spurred rapid growth in exports and employment. Although domestic entrepreneurs have played an increasingly important role as investors in free zone companies-for example, between 2000 and 2007, Honduran companies in the free zones grew by almost 700 percent, or from 13 to 103 companies-it was the role of local industrialists in establishing the free zone industrial parks in the later 1980s and early 1990s that was critical to catalyzing FDI into the sector, which in turn spurred rapid growth in exports and employment. ${ }^{7}$

Dominican Republic-In recent years, the Dominican Republic took a number of additional initiatives to promote forward linkages. The most important was Law 56-07 (May 2007), which opened up the domestic market fully (100 percent) to Free Zone (FZ) producers of key products, including textiles, clothing and accessories, hides and skins, and footwear and leather articles. The purpose of the amendment was to give an extra incentive to key sectors in which job losses have been heavy in recent years. Perhaps more important, it also extended the customs and fiscal benefits of FZs to domestic-based producers in these sectors. The amendment also opened up the possibility of FZ companies that provide logistical services (e.g., consolidation and storage of goods) to import and sell goods in the domestic market, subject to authorization and payment of the relevant duties. Despite these incentives, sales to the Dominican Republic re${ }^{6}$ The country enacted its first free zone law, Free Zone Area (Decree No. 131-98) and Law Establishing the Free Zone of Puerto Cortés (Ley Constitutiva de la Zona Libre de Puerto Cortés, Decree No. 356).which allowed export-oriented companies established in Puerto Cortés to enjoy a number of mostly fiscal incentive and these new legislation that broadened the geographic reach of the free zone policy to finally cover the entire country and encouraged partnership between local suppliers/domestic investors and FDI.

${ }^{7}$ WTO (World Trade Organization). 2003. “Trade Policy Review Honduras. "Report by the Secretariat, WT/TPR/S/120, August 29. Geneva: World Trade Organization. Accessed from WTO website on July 2017. 
main insignificant for most FZ companies (Willmore, 1995).

In terms of forward linkages, the FZ legislation is fairly conducive to supporting integration with the local market. FZ companies always have been free to export up to 20 percent of their production to the Dominican Republic domestic territory, provided they pay all relevant tariffs and taxes that imports from other countries incur. In addition, the import duty assessment on these exports does not take into account the value of any domestic components used and other value added components (Kaplinsky, 1993). The legislation is relatively favorable to supporting backward integration of FZs into the local economy. Suppliers from the domestic economy to FZ companies are exempt from import duties on the raw materials used in this production. This allows them to at least be on equal footing with competitors supplying the zones from outside the Dominican Republic. From the early days of the program, however, it was apparent that FZ companies imported virtually all their manufacturing inputs. The U.S. trade preference program for the apparel industry was designed to ensure that key inputs were sourced from the United States. Even after 2000, which allowed apparel producers to use inputs from all countries within the Caribbean, linkages have remained low (even at a regional level). The lack of supply links went beyond textiles and extended to capital equipment and even basic packaging materials. In the apparel sector, local spending (encompassing material inputs, capital equipment, water, electricity, and statutory payments of Social Security and training) in the early 2000s accounted for only 1.5 percent of the export value of FZ companies (Aggarwal, 2006). The Dominican Republic government, with the support of the U.S. Agency for International Development, set up a program in the 1990s to develop backward linkages with EPZs. Feasibility studies revealed abundant EPZ demand for textiles, precision plastic parts, metal stamping, machine shops, and tool, mold and die making. In successful FZ programs-for example, Malaysia and the Republic of Korea-the development of strong local clusters is acknowledged as making a significant contribution to the successful upgrading of FZ-based manufacturers by giving them access to competitively priced, world-class quality inputs (Schrank, 2001).

The Republic of Korea-When the Masan Zone began operations in 1971, domestic firms supplied just 3.3 percent of materials and intermediate goods to firms in the zone. Four years later, they supplied 25 percent and, eventually, 44 percent. Consequently, domestic value added increased steadily from 28 percent in 1971 to 52 percent in 1979. In all, the evidence indicates that the Korean government successfully encouraged backward linkages with local industries and subcontractors. Local companies supplying EPZ firms had preferential access to intermediate and raw materials. The zone administration also provided technical assistance to subcontracting firms (Healey, 1999). Getting SEZs firms to source materials locally-so-called backward linkages-is beneficial to the local economy in terms of increased output and employment and improved production efficiency, technological and managerial capabilities, and market diversification. Multi-National Companies (MNC) physically located within an SEZ may help 
prospective suppliers outside the SEZs set up production capacities, provide technical assistance and information to raise the quality of suppliers' products, or provide training and help in management and organization. SEZ companies may want to link to local suppliers for multiple reasons, among which are to achieve lower production costs, increase specialization, and better adapt technologies and products to local environments. Host governments, however, can create attractive conditions, facilitate contacts, and provide various direct or indirect incentives that make it cost-effective for foreign companies in SEZs to get supplies from local sources. The Republic of Korea's outsourcing program is one example and, in Shenzhen, SEZ administrators provided individually tailored directories listing prospective domestic suppliers (Healey, 1999).

Mauritius-The true success story of the Mauritius EPZ program was not job creation, investments, or exports per se, but rather the reform process, both economic and (critically) political, that it catalyzed. It is this reform that facilitated the structural transformation in the economy. Several important lessons can be drawn from the Mauritius case (Dommen \& Dommen, 1999). First, it highlights the importance of the political process and the importance of having a specific political champion behind the zones program, a lesson that we also see from cases such as China and Malaysia (especially Penang). Second, not only does the Mauritius case emphasize the importance of domestic investment in the zones program, it shows that integration of the zone program must go beyond the physical and financial-it must also be integrated strategically. Indeed, one of the main differences between zone programs that have been successful and sustainable and those that have either failed to take off or have become stagnant enclaves is the degree to which they have been integrated in the broader economic policy framework of the country (Dommen \& Dommen, 1999).

In Mauritius, the EPZ program featured as a pillar of the country's development strategy (Roberts, 1992). Zones generally have failed to have a great impact in most countries in part because they have been disconnected from wider economic strategies. Zone programs often are put in place and then left to operate on their own, with little effort to support domestic investment into the zones, to promote links, training, and upgrading. Unlocking the potential of zones requires strategic integration of the program along with the government playing a leading, active role in potentiating the impact of the zones. The program will need to strengthen their approach to social and environmental compliance issues, establishing clear standards and putting in place effective monitoring and evaluation ( $\mathrm{M} \& \mathrm{E}$ ) programs. At a national policy level, economic zones should be seen as opportunities to experiment with policy innovations (Roberts, 1992).

\subsection{The Objective of the Regulatory Framework}

The determinant structural feature of a zone is that it benefits from a different regulatory regime from that in the rest of the economy. Another important attribute of zones is the policy intent that informs their creation. Zones exist be- 
cause of their policy raison d'être: the social values or return they are expected to generate. Zones are created to generate or participate in the economic transformation of their host countries in a way that is faster or more effective than would be the case without them. They are developed to act as catalysts for growth (FIAS, 2008). What this means, however, varies significantly from country to country and has evolved considerably over the past 30 years. Over the past 30 years, the focus has progressively shifted toward the dynamic contribution of zones to economic restructuring and their use as instruments to enhance competitiveness (Watson, 2011).

The following four countries are presented here to show the unique specific types of objectives set in their legislation and to get note of the fact that a different set of specific objective is needed for industrial parks development than just a similar general objectives put in the overall industrial and/or investment legislations.

India-The IP Act of 2005 spells out the following objectives of the scheme: generation of additional economic activity, promotion of exports of goods and services; promotion of investment from domestic and foreign sources; creation of employment opportunities; development of infrastructure facilities; and maintenance of sovereignty and integrity of India, the security of the State and friendly relations with foreign States. Interestingly, all these objectives relate to static benefits of industrial parks (Saleman \& Jordan, 2014).

Sri Lanka-Law No. 4 of 1978 now known as the BOI (Bill of Industrial park) Act puts the following objectives: Foster and generate the economic development, Encourage FDI, Diversify the sources of foreign exchange and encourage the establishment and development of industrial enterprises (Aggarwal, 2005).

Bangladesh-Bangladesh Export Processing Zones Authority (BEPZA) Act of 1980 puts the following major objectives: foster and generate economic development by encouraging foreign investments; diversify the sources of foreign exchange earnings, encourage establishment and development of industries and commercial enterprises, generate productive employment opportunity and to upgrade labor and management skills through acquisition of advanced technology (Aggarwal, 2005).

Turkey-The industrial park policy has been constituted in the Five Year Development Plans by State Planning Organization (SPO) since 1970. These objectives have been; achieving balanced regional development, using industrial parks as an urban development planning tool, directing industrial development, decentralizing industry and reducing unemployment by providing incentives and disincentives for manufacturing firms (Turk, 2006). Before the industrial parks were established, Turkish industrialists were faced problems such as finding an appropriate place, setting up infrastructure foundation, and having required capital to run the firms. The industries that were developing unsystematically and without plan in the centre of cities and rural areas were damaging environment. With the aim of solving this problem, foundation of industrial parks had 
been decided in the five year development plan. The concept of industrial park has always been in development plans and programs in order to improve planned industry in Turkey (Turk, 2006).

In the planned development periods, industrial parks had three considerable objectives; First, to fulfill balanced growth by attracting industry to these regions and encourage undeveloped regions to grow but not to cause imbalance among the regions. Secondly, to fulfill planned urban growth by gathering unsystematic industry firms with a planned settlement system (FIAS, 2008). In this period, industrial parks came across a great number of problems since they did not have their own law. The industrial park law (Law no: 4562) was approved by the parliament in 2001. The aim of the law is to arrange establishment process, location selection, management, finance, and construction of industrial parks. The law of industrial park aim to regulate location selection, establishment and management of industrial parks as an urbanization and industrialization planning tool (Ganne \& Lecler, eds., 2009).

\subsection{Critical Areas That Need Regulatory Frameworks}

Location Decisions-First, it is important to separate political support from political objectives in zone projects. Although strong commitment from the government is needed, projects must be designed carefully on the basis of clear strategic plans. The commercial case must be present. Moreover, that commercial case must be based on sustainable sources of competitiveness, not on fiscal incentives. Second, despite the concept of zones as enclaves, in practice, their success is almost fully entwined with the competitiveness of the national economy and the national investment environment (Dinh, et al., 2012). Early proponents of industrial parks considered them as potential hubs for non-urban, decentralized industrial development. They favored placing IP's away from urban and populated centers to encourage job creation and economic development in rural areas and to reduce the rural-urban migration.

It soon became clear that industrial parks would not flourish in such an environment unless they were fitted with easy access to sea ports or airports, energy and water sources, good roads, above average communication facilities and available and adequately skilled workers. The Bataan Zone in the Philippines, located in a mountainous area some $160 \mathrm{~km}$ from Manila, is a prime example of a poor location choice. Despite the government spending nearly $\$ 200$ million in 1973 on building the zone, it failed to reach its goals due to its isolation from the country's industrial center and poor infrastructure. The same occurred to the Puerto Limon zone on Costa Rica's Atlantic/Caribbean cost. The Zone Franche d'Inga in Zaire is a third example of this miscalculation. It was located in a remote area of the country, with poor infrastructure to service it and few workers with adequate skills to satisfy its labor demands (The World Bank, 2012a).

The new philosophy highlights the importance of locating EPZs near or in industrial/urban areas. This satisfies the labor needs of the zone firms and allows 
for more spillover effects. Such a location choice also ensures more accessible and uninterrupted utilities, better infrastructure and services, and proximity to airports and sea ports (Zeng, 2015). Zones with proximate access to large consumer markets, suppliers, and labor tend to be more successful. In small markets, successful zone programs have tended in the first stage to take advantage of location, trade preferences, and labor arbitrage to create large-scale employment and to support a transition away from reliance on natural resource sectors toward the development of a light manufacturing sector. Many of the large-country successes used zones to leverage an existing comparative advantage in factor-cost-based manufacturing to facilitate a transition away from inward looking development policies to export-led growth. Such zones have offered foreign investors the potential to operate in a protected environment while giving governments the time and context to test reforms. The zones have also helped attract the foreign technology needed to support the transformation of domestic industrial capacity and facilitate scale economies in emerging sectors (Zeng, 2012b).

Investor selection-One step of the process of building and operating industrial parks is the stakeholders involved and the functions they have been assigned in identification of park location and identification of potential demand and overall dimensions. Demand identification is not exclusively taken on by a public entity rather consultants are hired by the government for demand identification. The investor selection process should be objective-technology capacity, company profile, willingness to disseminate technology, willingness to invest with public or private partnership, production capacity, employment level. The definition provided for industrial park investor should qualify those local suppliers to qualify them for same rights in terms of incentives and taxable income. The investor selection process should at least be conducted three months prior to the construction of the park than during the construction. This is because industrial parks should be built not on political bases but purely based on market demand (Watson, 2001).

Land Acquisition Procedure-The steps in the process can be broadly enumerated as: identification of park location; identification of potential demand and overall dimensions; procurement of land; design and dimensioning ("master planning") within the park; financing and financial structuring and planning; procurement of infrastructure building; construction of infrastructure; operation \& maintenance; and monitoring and evaluation (Saleman \& Jordan, 2014). These roles have been shared in many different ways between national, sub-national and local levels of government, and as many as four types of private sector firms: consultants hired by the government for demand identification, and/or designing and financing of the parks; "developers" who typically prepare the master plan for the parks; hired "constructors" and "operators" who construct the parks and manage their operation and maintenance; and "users", i.e. the private entrepreneurs occupying the park themselves. The design of industrial park programs land acquisition should consider each of these steps. In 
terms of specific roles, the regulator delegate actual implementation and focus on monitoring. In many federal states, like Nigeria and India, location selection was shared between state and center, dimensioning was pre-decided at between 150 to 250 acres and land provision was the explicit responsibility of state governments. This will ensure broad support to be received from both states and Centre for investors (World Bank, Overview of six Nigerian Economic Zones, 2012b).

\subsection{Designing an Organ in Charge of Regulating Parks}

Countries establish governing entities in place to support various administrative and development functions. Having a governing entity ensures seamless coordination among multiple parties. Large industrial complexes that deal with multiple stakeholders, such as government and various agencies, investors and NGOs, will benefit from a single point of contact. A governing entity also ensures the formulation of integrated development plans (Little, 2014). A large industrial complex needs an entity to plan and execute plans such as for land preparation, infrastructure, facilities, utilities and peripherals. This entity can serve as a developer or master planner in the coordination of these various activities. The third benefit of having a governing entity is to source and manage funds in order to finance the development of infrastructure and facilities in and around the park. Finally, the governing entity will drive processes for requesting or raising funds to finance infrastructure and facility projects, and ensure the right connections to funding pools are in place (e.g., a statutory body can request funds from the government, but a corporation can raise funds by issuing equity to its shareholders and investors (Farole, 2008). Having a sound governing entity can also bring strong marketing capability and focused promotional strategies to attract investors. The overarching question is what the governance options are for the industrial park. The first question faced by a governing entity relates to its scope of function. Secondly, there is a need for clarity around which projects should be funded by which entity (e.g., the federal or state government, investors, or the development corporation such as the case may be). The level of authority given to the governing entity and the land over which it has jurisdiction are also important to define. Finally, the question of revenue allocation needs to be addressed (Little, 2014).

\subsubsection{The Governance Models}

Although there could be variations around the same theme, there are essentially three governance models: a statutory body, corporation and a combination of both (Little, 2014). A statutory body is formed by a legislative act, and is given certain powers as defined by this act. It has the mandate to both develop and administer the park. JTC in Singapore was established in 1968, and is the main developer and manager of industrial estates in Singapore. The efficiency of the government of Singapore has contributed to the success of JTC through centralization of economic development activities (i.e., multiple projects were done in 
conjunction with the Economic Development Board of Singapore). A corporation is a profit-driven entity created to develop and administer an industrial complex. The Port of Rotterdam Authority (PRA), formerly a department of the Municipality of Rotterdam, was corporatized in 2004 so it could finance the port activities and better respond to client demands. Positive state and government involvement and readiness of infrastructure from the onset have also contributed to its success to date. In the third model, a statutory body and a corporation are set up, respectively, for administration and development of the complex (FIAS, 2008). In this model, the statutory body protects the government's interests and administers the park. The corporation holds the land and develops the complex; land is rented to investors, generating sustainable income.

\subsubsection{Selection of the Best Governance Model}

The selection of the governance model needs to address the primary objective of the park. If the park needs to remain close to a country's strategic objectives and time is not the primary concern, then the government may want to set up a statutory body to administer it. This will facilitate interaction with federal and state agencies and if these are run efficiently, as is certainly the case with the Jurong Town Corporation, this option is a viable one. But if the government's primary objective is to showcase the country's attractiveness to potential investors, it may want to set up a corporation which can run the park more efficiently and is better able to attract talent, as is the case with the Port of Rotterdam Authority. Alternatively, this second option could be leveraged during the park's initial stages of development in order to get it off the ground quickly while a statutory body is set up to administer it at later stages coordination (Little, 2014). In most countries, the IP authority has primary responsibility for marketing and promotion, and usually for investor aftercare as well, while a separate national investment promotion authority (IPA) performs these roles for FDI outside the zones. While a separation of these agencies is usually advisable, it can also be a source of operational disconnect between the agencies, resulting in poor coordination of activities. In most cases, it appears that the national IPA does provide some high-level promotional support to the SEZ authority but there is generally little coordination of marketing planning and execution, and no formal process for handoff or cross-support of investor aftercare between the agencies (FIAS, 2008). Other zone programs run into similar challenges at the local level. For example, in Nigeria, much of the investment promotion in support of zones comes through state governments; although they might coordinate with a specific zone in the state, there is little higher level coordination with national SEZ promotion efforts. In Vietnam, there is no national-level responsibility for promoting zones, with (often independent) promotional efforts taking place at the level of provincial government, regional investment promotion centers (linked to the Ministry of Planning), and individual zone management boards (FIAS, 2008). Best practice is to have a cooperative approach, involving a coalition of interested stakeholders that includes the zone developer, local business associa- 
tions and chambers of commerce, and the investors that operate in the zones. In smaller countries or countries with a strong corporatist model (for example, Costa Rica and the Dominican Republic), it may be possible to achieve effective informal coordination among agencies and other stakeholders, but in most cases coordination is best achieved through formal means (Little, 2014). In some of the cases assessed in a study (e.g., Tanzania, Nigeria, Kenya, and Bangladesh), the lack of formal institutional links among the agencies is an important source of operational disconnect (Brautigam, Farole, \& Tang, 2010). In other cases (e.g., Kenya, the Dominican Republic, Ghana), the SEZ authority and the IPA sit on each other's management boards, although this is usually not enough to ensure active, on-the-ground coordination. Other approaches that have been used internationally include signing an MOU, establishing a service agreement, or establishing a marketing and promotion committee or board (Little, 2014).

\section{Industrial Parks Regulation in Ethiopia}

Ethiopia initiated its IP program in a government fiscal plan in the first GTP (Growth and Transformation Plan) ${ }^{8}$ which is phased, yet ad hoc manner, resulting in mixed results and delayed implementation. The first GTP (which is named GTP I) envisioned the establishment of five industrial parks in the country: Bole-Lemi and Kilinto Industrial Parks in Addis Ababa, and one each in Hawassa, Dire Dawa and Kombolcha (MOFED, 2010, Growth and Transformation Plan 2010/11-2014/15). To date, the first phase of Bole-Lemi has been developed and is partially functioning. Bole-Lemi Phase I consists of twenty (20) factory sheds that are leased to 12 manufacturing firms to produce and export leather and apparel goods. The Industry Park is still not fully completed and is thus functioning partially. In addition a number of private industrial zones have been sanctioned with the Eastern Industrial Zone (EIZ) in operation. Both the Bole-Lemi I and EIZ have faced a number of challenges in the planning design phases that led to delayed implementation and mixed performance. ${ }^{9}$

The inexistence of IP-related policies and management experience led to multiple challenges in planning and implementing of the EIZ and Bole-Lemi 1 industrial parks. A range of issues have held back the performance of the program including: lack of an effective and functioning policy, regulatory and institutional framework; weak strategic planning and demand driven approach; poor on-and-off site infrastructure planning; lack of specific on-and-off-site costing, performance agreements, and economic and financial analysis; absence of institutional capacity to oversee IP development; inefficient procedures and controls, ${ }^{8}$ The MInistry of FInance and and Economic Development is responsible for establishing a system for the preparation and implementation of national development plans. Accordingly the Minstry has prepared the national 5 years growth and transformation plan (GTP) and The council of Ministers and The House of peoples representative endorsed and adopted the GDP on November 2010 as the national planning document of the country for the period 2010/11-2014/15.

${ }^{9}$ At the time of this writing, Mekelle and Kombolcha industrial parks have just ianugurated while Jimma Industry park and Diredawa Industry parks are ready for inauguration. 
including customs administration; lack of systematic investment promotion to attract committed anchor investors; and deficiencies in designing and implementing a linkages program, a communications and outreach strategy, and establishing and tracking performance indicators. These factors combined with a poor business environment and weak eco-system related to skills and technology, have not led to the envisaged outcomes. ${ }^{10}$ The Government of Ethiopia (GoE) has embarked on an IP development program, partly in recognition that systematic investment-climate reforms in multiple areas take time to address and are politically challenging to implement. The IPs in Ethiopia aim to address the market failures related to land access, infrastructure, and logistics costs, as well as the high costs of doing business. The IPs can potentially be an effective instrument that offers investors the chance to operate in an improved investment climate vis-à-vis the national investment climate while giving the government time and a natural experiment for testing policy and regulatory reform to support industrialization, as evidenced from countries in East Asia and Latin America regions (Aggarwal, 2010). According to The World Bank, the IP strategy in Ethiopia hinges on attracting FDI in the export-led and labor-intensive manufacturing sector. The Government is emulating the path of the East Asian countries that have successfully managed to use industrial parks as a platform to catalyze investments-FDI and domestic-in creating jobs, generating exports, and foreign exchange. Focusing on the manufacturing sector, Ethiopia is prioritizing FDI in specific sectors: textile and apparel, leather and leather products, agro-processing, and pharmaceuticals and chemicals. The imperative is to build on the country's agricultural foundations by moving toward new tradable activities in manufacturing that absorb large numbers of young and semi-skilled workers. Ethiopia's potential in the light manufacturing sector is significant, but faces binding constraints related to access to land, infrastructure, trade logistics, and customs regulations as well as skills gap (World Bank (2014b, 2014). This section mainly discusses the Ethiopian IP regime, areas, instruments, objectives of regulations and as such the section is organized into six sub-sections which mainly are arranged and presented here in following order.

\subsection{The Areas \& Instruments of Regulation}

The Industry Development Strategy of the country has put in place the principles that primarily focus on the promotion of agricultural-led industrialization, exported development, and expansion of labor intensive industries. This strategy refers to those industries which are primarily involved in the production of manufactured goods. It is also tried to include other industrial classified sectors in the document other than the manufacturing industries. The strategy also affirms that building up of industrialization can be realized only through the implementation of agricultural and rural centered economic and industrial development strategy. The strategy also affirms that industrial competitive capacity

\footnotetext{
${ }^{10}$ World Bank, (2013b), Ethiopia Industrial Zone Prefeasibility Study, World Bank, Washington, DC.
} 
would be achieved only when it is possible to promote strong export oriented industry and be able to transform to and implement this industrial competitiveness in other industrial sectors. The strategy also puts implementing effective domestic-foreign investment partnership method recognizing than foreign investment has disadvantages in connection with profit and dividend repatriation after the foreign based company is commencing its operational activities (Industrial Development Strategy of Ethiopia, 2002). Finally the strategy sums up affirming the need to focus on the expansion of labor intensive industry direction abundant and hard working labor force as the basis of the competitiveness of companies so that the industries may have the opportunity of becoming competitive by utilizing this abundant and hard working force. Some of the industry sub-sectors that are given top primary in the development effort of the Government are: 1) Textile and Garment Industry, 2) Meat, Leather and Leather Products Industry, 3) Agro-Processing Industries, 4) Construction Industry, 5) Strengthen Micro and Small Companies.

The industrial development strategies focuses on industries which are labor intensive and having wide market; have broad linkages with the rest of the economy; use agricultural products as input; export-oriented and import substituting; and industries that can contribute for faster technology transfer. The priority sectors in the manufacturing sector are agro-processing, textile and garment, Leather and leather products, metal and engineering, and chemical and pharmaceutical sectors. The overall goal of the industrial development strategy is to bring about structural change in the economy through industrial development. Specifically it is aimed at by increasing the share of the industry sector as $\%$ of the GDP from the current $13 \%$ to $27 \%$ by 2025 , and also increasing the share of the manufacturing sector as \% of the GDP from the current $4 \%$ to $17 \%$ by the year 2025. In accordance to this overall goal, specific strategic objectives are set (Industrial Development Strategy of Ethiopia, 2002). The five strategic objectives, which guide the implementation strategies and programs, are: 1) to further expand and develop the existing manufacturing industry priority sectors; 2) to diversify the manufacturing sector to new sectors; 3 ) to enhance enterprise cultivation and entrepreneurship; 4) to increase public, private and foreign investment; and 5) to develop and operate industrial zones and cities. A number of key strategies that need to be pursued in order to achieve the stated vision and goal are selected. These key implementation strategies are: 1) Ensuring conducive business environment; 2) Availing competent human resource; 3) Availing quality industrial inputs for value-addition; 4) Developing and diversifying local, regional, and global markets; 5) Enhancing technology transfer; and 6) Developing and providing institutional support.

\subsection{Industrial Parks Regulatory Organs}

From 2012 up to 2014-industrial parks had been developed and regulated with a department under Ministry of Industry. The ministry were led by three state ministers in order to alleviate widened burdens of the ministry i.e. 1) one directo- 
rate led by a state minister to address the widened load in charge of the development of industrial zones, 2) one directorate led by state minister in charge of the development of textiles and 3) one directorate led by state minister for leather sectors and responsible for regulating agro processing and the chemical sector. ${ }^{11}$ The Ministry of Industry (MoI) awarded a 633 million Br contract to a total of 13 domestic construction companies to develop part of the Bole Lemi Industrial Zone that covers around 156 hectares of land, for investors that have shown interest to build medium and large scale industries including eight South Korean companies engaged in textile and garment sectors. The ministry, which is entrusted to manage the plots given for industrial purposes, selected the companies out of 26 contractors along with the Ministry of Urban Development \& Construction (MoUDC), Ethiopian contractors Association (ECA) and $\mathrm{MH}$ Consultant, by assessing their previous performances on government projects such as construction of universities and government office. ${ }^{12}$ From 2014 onwards industrial parks started to develop by public enterprise named "Corporation". In order to regulate industry zones, the government had approved the establishment of the Ethiopian Industrial Zones Development Corporation (IZDC) in 2012 under the MoI, but the corporation was reestablished as the Ethiopian Industrial Park Development Corporation (IPDC) by the beginning of 2014 with a new directive. The Corporation was established as one of the public enterprises with the mandate to avail serviced industrial land; pre-built sheds equipped with all-encompassing utilities and infrastructure facilities and operate wide ranges of industrial parks in the country. ${ }^{13}$

\section{1) Ethiopian Industrial Parks Development Corporation (EIPDC)}

The Ethiopian Industrial Parks Development Corporation (EIPDC) established as a Public Enterprise under the Council of Ministers Regulation No.326/2014, is mandated to: develop and administer Industrial Parks, lease developed land and lease and transfer, through sale, constructions thereon; Prepare detailed national Industrial Parks Master plan based on the national special Master plan, and serve as the industrial park land bank in accordance with the agreements concluded with regional governments; In collaboration with the concerned bodies, ensure that necessary infrastructure is accessible to Industrial Park developers; Outsource, though management contracts, when it is deemed necessary, the management of Industrial Parks; Promote extensively the benefits of Industrial Parks and thereby attract investors to the parks; In line with directives and policy guidelines issued by the Ministry of Finance and Economic De-

\footnotetext{
${ }^{11}$ It must be noted that at the time of this writing, October 2018, Ethiopian Parliament proclaimed a legislation for reestablishment of the executive organ of the Federal Government in which the Ministry of Industry and Ministry of Trade are merged into one ministry-Ministry of Trade and Industry and the duties of the new Ministry is confined for domestic investors while Investment Commission is deemed to assume its duty mainly on foreign investors.

${ }^{12}$ MOTI, 2012, Report on the Prospects and Current Status of Bole-Lemi Industrial Park, accessed from the ministry on June 2017, unpublished.

${ }^{13}$ FDRE Regulation (2014b), "Industrial Parks Development Corporation Establishment Council of Ministers Regulation No.326/2014,” Federal Negarit Gazettte $21^{\text {st }}$ year No.02, (Addis Ababa, 5 December 2014).
} 
velopment, sell and pledge bonds and negotiate and sign loan agreement with local and international financial sources; Under the regulation, the corporation is organized based on the following major principles and structures which include a body to be designated by the government shall be supervising authority of the corporation, the corporation has limited liability, the corporation will have a capital to be allocated by the government.

\section{2) The Ethiopian Investment Commission}

The Ethiopian Investment Commission established as "autonomous" federal government office under the Council of Ministers Regulation No.313/2014, has the following power and structures: the commission is composed of one commissioner and deputy commissioners who serve as Chief Executive Officers of the commission and subjected to the direction of the investment Board; serves as secretariat of the board and implement the decision of the board collaborating with relevant government; exercise powers assigned to it under Article 28 of the investment proclamation 769/2012.

The powers conferred to the commission include: 1) serve as a nucleus for matters of investment and promote, coordinate and enhance activities thereon; 2) initiate policy and implementation measures needed to create a conducive and competitive investment climate and follow up the implementation of same upon approval; 3) negotiate bilateral investment promotion and protection treaties with other countries where potential investment is likely to flow into the country and sign same upon approval by the Council of Ministers; 4) prepare and distribute pamphlets, brochures, films and other materials, and organize such activities as exhibitions, workshops and seminars locally or abroad as may be appropriate, participate in similar activities and conduct trainings with a view to encourage and promote investment and build the image of the country; 5) realize liaison and coordination between investors, public offices, regional governments and other relevant organs, with a view to enhancing investment; 6) prepare and promote concrete investment opportunity profiles, provide upon request, match-making service of possible joint investment partners; 7) issue, renew and cancel investment permits within its jurisdiction and register investment capital brought into the country by foreign investors; 8) register technology transfer agreements related to investments; 9) register export-oriented non-equity based collaboration agreements made between a domestic investor and a foreign enterprise. ${ }^{14}$

Under Industrial Parks proclamation 886/2015, investment commission is also given power and duty to: 1) register and give legal personality to industrial park developer, industrial park operator; 2) take administrative measures on IP residents who transfers immovable property to third party; 3) revoke certificate of industrial park residency; 4) shall provide one-stop shop service within the park; 5) handle \& decide on appeals lodged against measures taken by competent authority against IP developer, IP operator, industrial park enterprise \& in${ }^{14}$ FDRE Regulation (2014a), "Ethiopian investment Board and Ethiopian Investment Commission Establishment Council of Ministers Regulation No.313/2014,” Federal Negarit Gazettte $20^{\text {th }}$ year No.63, (Addis Ababa, 14 August 2014). 
dividual park resident; 6) take measures against industrial park enterprise upon violating the proclamation or any applicable law; and 7) approve the agreement concluded between IP enterprise and IP developer or operator. ${ }^{15}$

\section{3) Ethiopian Investment Board}

Council of Ministers Regulation No. 313/2014 for establishment of Ethiopian Investment Board and Ethiopian Investment Commission, puts the following major power and duties of the board in relation to industrial parks: approve the agreement concluded between industrial park operator and developer, approve the transfer of leased and developed industrial park land to third parties in a written form, designates industrial parks upon fulfillment of certain criteria, shall designate and oversee the administration and supervision of industrial parks, shall decide on complaints submitted by IP developer, operator and enterprises on the decision of the commission., shall reprimand and/or suspend the license given to IP developer or operator upon violation of applicable laws, shall serve as appellate for any decision made by the commission. ${ }^{16}$

\section{4) The Ministries}

Industrial parks proclamation $886 / 2015$, also gives some regulatory role to the following three ministries. The Ministry of Environment and Forest is obliged to establish an office within an industrial park for the application, supervision, protection and enforcement of environmental norms, standards, safeguards and management and mitigation plan within the Industrial Park. The proclamation leaves the detail environmental obligation to be specified in the future. The Ministry of Labor \& Social Affairs is obliged to establish rules \& procedures on labor issues in consultation with the Ministry of Industry on the basis of tripartite modality, the detail of which is to be specified in the upcoming regulation. ${ }^{17}$

From the above four regulatory organs stipulated under the proclamations and regulations and the power and duties assigned to each of them, the following major analysis and regulatory ambiguities can be deducted from the rules. First, under the industrial parks proclamation, the regulation of labor, environmental and technology transfer is out of the power and duties of either the commission or the board. The regulation is left for three different ministries, which makes it less practical to regulate. ${ }^{18}$ Provision of one-stop-shop services is the mandate of the commission while at the same time it is appellate body for any grievance or appeal from developer and operator, which makes the grievance provision of one stop service ineffective. ${ }^{19}$ The Investment commission is ${ }^{15}$ FDRE Proclamation, (2015), "Industrial Parks proclamation No.886/2015, cumulative reading of Article" 17-18; 27; and 29-31.

${ }^{16}$ The powers of the board is also enumerated under "Industrial Parks proclamation No.886/2015, Article" 17-18.

${ }^{17}$ Cumulative reading of Article 28 (Labor affairs for Ministry of labor and Technology transfer to the ministry of Industry), Article 29 (Ministry of Industry shall assist in marketing, extension service and technology inputs).

${ }^{18}$ Supra Note 14, FDRE Proclamation, (2015), Industrial Parks proclamation No.886/2015, cumulative reading of Article 24(2); Article 28(3); Article 28(5); and Article 29(4). It is quite important to note the experience of India and South Korea and empirical theories explained by Peter G.Warr under Chapter Two. 
given power to take measures against industrial park enterprise upon violating the proclamation or any applicable law while the investment board is given power to reprimand and/or suspend the license given to IP developer or operator upon violation of applicable laws. ${ }^{20}$ This power division between the two organs as to industrial park enterprise and IP developer or operator is not clear. The cause for difference in treating the enterprise differently from developer/operator should be justified.

The approval of agreements concluded between industrial park operator and developer and the transfer of leased and developed industrial park land to third parties is given to the board while the commission approves the agreement concluded between IP enterprise and IP developer or operator. ${ }^{21}$ This difference in power will have effect on developing central, independent and harmonized decision making process. On the other way, in relation to complaint and appellate power, the commission is decision maker in some areas as well as appellate body while the board is a decision maker as well as appellate body on some different areas. This will create a lot of confusion and less well-defined, less centralized complaint and appellate bodies which will create unfriendly business and regulatory environment.

\subsection{Ethiopian Industrial Parks Regulatory Objectives}

The rules, under proclamation No. 886/2015, which specifically apply to activities undertaken in industrial parks, have set the following five objectives: regulating the designation, development and operation of industrial parks; contributing towards the development of the country's technological and industrial infrastructures; encouraging private sector participation in manufacturing industries and related investments; enhancing the competitiveness of the country's economic development; creating ample job opportunities and achieve sustainable economic development. ${ }^{22}$ These objectives are not different from that of the general investment objectives set under investment law of the country. ${ }^{23}$ In addition, these objectives do not prioritize and failed to embody clear rules on location (designation) $)^{24}$ and investor selection rules (industrial park developer). ${ }^{25}$ The proclamation makes the development and operation of parks as public affairs than private driven market based development.

${ }^{19}$ FDRE Proclamation, (2015), Industrial Parks proclamation No. 886/2015, cumulative reading of Article 27 (2); Article 30 (5) and (6).

${ }^{20}$ FDRE Proclamation, (2015), Industrial Parks proclamation No. 886/2015, cumulative reading of Article 30 (1) and Article 30 (5).

${ }^{21}$ FDRE Proclamation, (2015), Industrial Parks proclamation No. 886/2015, cumulative reading of Article 22 (7) and Article 22 (3).

${ }^{22}$ FDRE Proclamation, (2015), Industrial Parks proclamation No. 886/2015, Article 4.

${ }^{23}$ Supra Note 39, FDRE Proclamation, (2012), Investment Proclamation No. 769/2012, Article 5.

${ }^{24}$ The Industrial park proclamation 886/2015 under Article 25 did not mention the need of feasibility study nor any business driven decision to be made.

${ }^{25}$ The Industrial park proclamation 886/2015 under Article 26 left the selection of industrial park developer to be affected in accordance with the upcoming regulation. However, the regulation is not yet promulgated while 11 foreign companies are manufacturing in Hawassa industry park and still the government is inaugurating additional 6 industrial parks this year. 


\subsection{Regulatory Areas That Need Specific and Clear Provisions}

Location decision-The industrial parks or industrial development strategy did not put any special attention to location decision nor does the industrial parks establishment proclamation provide hints on location matters. Specifically location decision of industrial parks is made a matter of policy decision without any hint of whether it took into account geographic or regional diversification or may be urban development. ${ }^{26}$ Specifically the rules of investment law take locations decision for investment incentive purposes-those parks near Addis Ababa get fewer years of tax incentives than those located very far. ${ }^{27}$ The rules neither put any obligations or limitations on the government in making a location decision-specifically in areas of demand identification, backward and forward linkage and local content.

Investor selection-Industrial parks proclamation and investment laws of the country do not have a clear, competitive and transparent way of selecting investors for industrial park development and operation purposes. It has always has been based on first-come-served type of service delivery in which, based on foreign experience, the rules should guarantee investor selection process free from any bias, discrimination based on origin and obligatory rules on government on provision of onsite and offsite infrastructure. The existing rules simply put some less stringent criteria of capital and documentary compliances that a foreign and domestic investor has to follow. ${ }^{28}$ The licensing requirement do not sufficiently oblige the investor to be selected demonstrate its capacity to achieve the objectives of industrial parks development and regulation specifically on labor, export, local content, environmental compliance, backward and inward linkage with local economy, skill and technological transfer.

Land Acquisition Procedure-The investment laws and specifically, the industrial parks laws of the country just refer the procedures of land acquisition of any urban land or rural land put under the proclamation 455/2005. The proclamation put joint collaboration of federal and states on displacement, compensation and rehabilitation issues. Based on best international practice it hasn't specifically left the displacement issue for states and the compensation to the federal and rehabilitation again to the states. This will create a lot of problems on the adequacy of the compensation, well-being and rehabilitation of displaced people and nearby residents. The location decision should accompany detail master and strategic plan of the industrial parks as to the expansion and the related burden it created on the livelihood of the residents.

\subsection{The Current Situation of Operational Industrial Parks}

These four industrial parks are selected based o the fact that they are the only ${ }^{26}$ FDRE Proclamation, (2015), Industrial Parks proclamation No. 886/2015, Article 25.

${ }^{27}$ FDRE Regulation, (2012), Investment Incentives and Investment areas Reserved for Domestic Investors Council of Ministers Regulation No. 270/2012, Negarit Gazette, 19 Year No.4, Addis Ababa, $29^{\text {th }}$ November 2012. Specifically you may see the incentive schedule attached with the regulation.

${ }^{28}$ Investment Proclamation No. 769/2012, Article 11 and 12. 
industrial parks fully operational during the time this research is conducted and based on the field visit to these four operational industrial parks, throughout 2017, with specific on general profile, ownership structure, development phasing, financing, infrastructure status, business prospects, and key regulatory challenges for each zone the following facts are presented.

The Bole Lemi Industrial Zone (BLIZ):-is located $5 \mathrm{~km}$ west of Addis Ababa on a $5 \mathrm{~km}$ circular Goro road with the Kotebe River to the south and Debrezeit road to the north. The development of Bole-Lemi Industrial zone was first instructed by the late Prime Minister Meles Zenawi after his trip to Seoul, South Korea, where he lobbied the Korean investors to invest in Ethiopia amplifying the investment opportunities in the country in the January 2012. The Ministry of Industry entrusted to develop, construct and manage the plots to be given for industrial purposes directly gone into finding a place near Addis Ababa around the main road for the construction of the industry zone. The development objective of the BLIZ initially is put "to open to eight South Korean garment and textile investors who showed interest during the primier visit and for other local or foreign investors who comes up with a sound proposal willing to invest in the manufacturing sector and for export purposes." ${ }^{29}$

Ethiopian first-grade contractors were entrusted to construct standard five factories and four office blocks, of which two of the factories rest on 10,000 sqm each, while the remaining will occupy $5000 \mathrm{sqm}$. While initially the construction was expected to take up to 9 months to complete, it took five years to be ready for start of operation. The Ministry of Industry confirms that the delay occurred because relocating the households who reside in the area has taken a lot of time. ${ }^{30}$ An effort to establish one stop shop has failed, as we have noticed during field visit, and according to the investors, only the customs authority delegate one personnel is available at office. Even worse the personnel is not fully empowered to provide tax or custom clearance on spot, had the power of facilitation which forced the investors to move $50 \mathrm{~km}$ away to Kality customs office for export clearance. ${ }^{31}$ Foreign manufacturing firms operating in the Bole-Lemi Industrial Park have reported their challenges to the Industrial Affairs Standing Committee of the House of People's Representatives during the field visit of the committee on 26 June 2016. Errors during the construction of the industrial park are now costing the factories who have leased out sheds there. Leakages of water pipelines across the park have been costing the companies in the form of extra water bills, the standing committee confirmed. A Korean textile firm, Shins, for instance, is asked to pay close to one million birr in water bills which is wildly beyond the company's water usage, according to the standing committee's report which compiled the grievances of companies in Bole-Lemi I. The

${ }^{29}$ MOTI, The detail report on the current status of Bole-Lemi Industry Park, unpublicized report, accessed from The Ministry of Industry Department of Industry Parks on August 2017.

${ }^{30}$ Ibid.

${ }^{31}$ Based on the interview held with the south Korean company acting manager on July 2017. 
standing committee presented its findings in the presence of senior responsible government officials including Tadesse Haile, State Minister of Industry. ${ }^{32}$

Inaccurate slope utilized in the construction of the drainage lines is now causing flood on facilities, while lack of water supply for almost a week is forcing them to transport water from other areas using trucks, according to the deputy chairman of the standing committee who presented the report. Lack of a reliable water supply for fire emergency, sanitation and difficult road access to the facility has created a bad working environment in the Bole-Lemi Industrial Park, according to the same report.. Absence of a one stop service at the industrial park is also another bottleneck identified from the companies' complaints. Service providers such as Customs, Textile Industry Development Institute, Leather Development Institute, Immigration Office and Banks, should avail their services in one window at industrial parks, according the plan set out by the government. However, it is only the Customs Office which is present in the Bole-Lemi Industry Park, according to the report. Even if the Custom Office is there, it is not providing full services forcing companies to travel to Kaliti Customs Office, very far way form the park. ${ }^{33}$

The zone operator indicated that several marketing and training activities planned have never been conducted and a large scale marketing event planned in foreign countries does not materialize. According to the contractors', development of the industry zone should have consisted of the development of construction works for the provision of necessary infrastructure facilities, including site clearance and leveling (partial), internal roads, landscaping, water supply and sewerage, power supply, telecommunications, gas supply, industrial workshops, warehousing/logistics/storage facilities, public/commercial facilities, residential buildings and environment protection facilities. ${ }^{34}$ Based on the field visit and group discussion with the enterprises, the industry zone was developed without feasibility study as to answer what kind of manufacturing activities fit for the zone and assess whether light industry including furniture, textile \& garments, footwear \& headwear, construction \& building materials, household electrical appliances $\&$ other consumer products will be the right choice. The zone hasn't completed the master plan and feasibility study and had not engaged in active marketing efforts. The land has been acquired without clean title. The State is in the process of engaging a company to begin the master plan work, and also begin the environmental baseline studies for the required infrastructure. Moving forward, the key challenges were/ would be the on-site infrastructure, adequate of zone management expertise, environmental and resettlement issues. The key constraints from the zone could be to identify the right partner(s) which can provide solid zone management and operational expertise. ${ }^{35}$

Ayka-Addis Industry Zone-Ayka Addis, the Ethiopian subsidiary of the

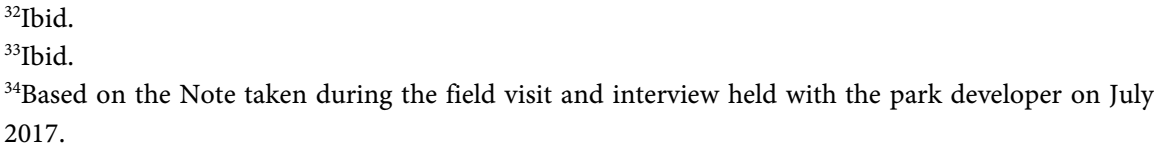


Turkish textile giant Ayka Textile, inaugurated in 2010 at a cost of US $\$ 140$ million at Alemgena, $20 \mathrm{~km}$ west of Addis Ababa, creating jobs approximately 7500 people, is the oldest and biggest Turkish textile company in the country. The factory is owned by Yusuf Aydeniz and his partner Gurchay Kavlakl and manufactures different kinds thread, 70,000 readymade clothing and other textile products. The factory also spins and dyes over 99,000 tons of garments. Ayka Addis has the capacity to export textile products worth US\$100 million a year per annum and accounted for 60 percent of the textile and garment export of Ethiopia since 2013/14. ${ }^{36}$ Accounting for more than half of the annual export revenue from the textile sector, Ayka continues to be a dominate force in the Ethiopian textile vision. For instance, in that particular year, it has made export of 63 million dollars worth of textile and garment products out of total 111.45 million dollars. Actually, it has 100 million dollars installed capacity, which it was not able to attain so far. ${ }^{37}$

As far as, the challenges are concerned, logistic issues: such as port handling fees and in-land transportation cost are most undercutting for textile exporters working from Ethiopia. For instance, port handling fee for import and export from Ethiopia at Djibouti Port is 1150 and 650 dollars, respectively, in contrast to other competitive port handlers which chargers not more than 200 dollars In-land transport is not that different either. By Ayka's calculations, transportation cost of 2175 dollars for import and 1400 for export measured by a standard 40 -feet container is outrageous in the eyes of 200 to 300 dollars international prices. But, the lag time is another headache for exporters like Ayka. Receiving import of inputs and raw materials in Ethiopia is quite a time taking undertaking, Yusuf admits. "Import could take as much as three months to arrive at the factory gate and that is a time I cannot afford to wait," he says. And hence, Ayka keeps 30 million dollars worth raw materials like chemicals, yarn, fabric, dye staff and many others at any given time. ${ }^{38}$ The unresolved challenge is cited to be inadequate quality cotton supply in the country. Even if the company uses organic cotton in the production of around 60 percent of the products, most Ethiopian producers don't have the certification. Hence, the company imports raw cotton from India and now received a plot of land in Omo Valley for the production of raw organic cotton. Turkish textile giant's Ethiopian subsidiary, Ayka Addis Textile Company has told Member of Parliaments, during the visit held in June 2016 that the costs structure in its supply chain in Ethiopia is making it uncompetitive in the global market. Ayka's predicament is also something that has captured the attention of the standing committee's investigation. It has been losing five million dollars every year because of a very poor quality of cot-

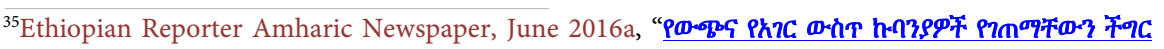

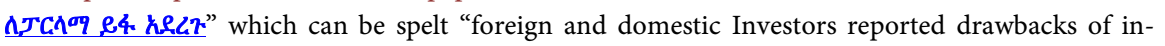
vestment to the parliament" accessed from https://www.ethiopianreporter.com on June 2016. ${ }^{36}$ Ibid.

${ }^{37}$ Based on the interview conducted with Ayka Addis General Mnager Mr, Yusuf Aydeniz on July 2017.

${ }^{38}$ Ibid.
} 
ton supply, while losing another eight million owing to the inflated liquid petroleum gas and coal supply's prices, the report read. ${ }^{39}$ High logistics cost is the other major challenge for Ayka and other textile companies such as MNS Textile. "We have been paying 1110 dollars while transporting a container of goods from the Port of Djibouti to Addis Ababa and 650 dollars while forwarding their containerized export to the port which is even higher than marine cost," according to MNS, another company that have lodged its compliant for the standing committee. Moving forward, the key challenges would be the on-site infrastructure, adequate of zone management expertise, environmental and resettlement issues.

Hawassa Industrial Park-Hawassa Industrial park located in the SSNPR State, $275 \mathrm{Km}$ south of Addis Ababa, applauded as flagship park by the government, specializes in textile \& garment with 130 ha in Phase I built 22 sheds of $11,000 \mathrm{~m}^{2}, 12$ sheds of $5500 \mathrm{~m}^{2}$ and 3 specialized sheds on a 30 ha factory buildings, business district, residential quarters. The park is built at a cost of US $\$ 246$ million after the government succeeded its attempt to get a finance source of a one billion dollar oversubscribed debut Eurobond from Europe and the United States (US), with a $6.625 \mathrm{pc}$ interest rate. ${ }^{40}$ The park were built by well-known Chinese contractor CCEC, applaused for fulfulling international standards, which took only 9 months to finish the overall construction and inaugurated by former Prime Minister Hailemariam Desalegn on 07 July 2016. Unlike the previous model of industrial zones in which Ethiopia tried to create industrial zones for all sort of industries in one place the unique feature of the park is purely export processing zone specializing only for garments/apparel production. ${ }^{41}$ The most visible challenge cited by the companies include: 1) sixty seven Ethiopian employee who had been offered training, from the expense of investors, in Malaysia had immediately resigned after return without much contribution to the investors 2) the availability of local raw materials-specially the supply of certified organic cotton is almost non-existent. 3) the existence of lacal small and medium enterprises 4) waste management system, specifically the water purified after factory production will be directed to Hawassa Lake which had created concern on environmental activists and local residents. ${ }^{42}$ The land where the park is build had been under the possession of SNNPR Seeds Enterprise, a public enterprise established under the former SNNPR State Agriculture Bureau (now renamed as SNNPR Sate Agriculture \& Natural Resources Development Bureau)

\footnotetext{
${ }^{39}$ Based on the field visit conducted by the Author on July 2017 and interview held with IPDC head on June 2017.

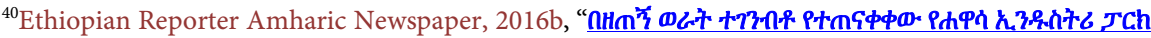
$\underline{\rho} \boldsymbol{\omega}$ to be administered by foreign Companies" accessed on 16 July 2016.

${ }^{41}$ The most internationally well-known garment manufacturers have established business in Hawassa Industry Park specializing in textile and garment production purely for export. Well-known international companies include JP Textile (Chinese), PVH (USA), TAL Textile (Indonesian), KGG Garment (Sri Lankan), Indaramani Garment (Sri Lankan).

${ }^{42}$ Industrial Park Development Corporation, 2018, Hawassa industrial park current situations, unpublicized report, IPDC, January 2018. Accessed from IPDC on January 2018.
} 
for scientific experimentation of seeds. Hence, initially the designated land has no residents or businesses, so there seem to be no resettlement issues. The off-site infrastructure is in a relative good condition, with old paved state roads which goes toward Moyale, to the boarder of Kenya, Mombasa, which is $397 \mathrm{Km}$ away from Hawassa.

Eastern Industry Zone-The industry zone has a layered structure, with a bilateral coordination committee between the Chinese and Ethiopian governments; the Ethiopian management and service agency of the industrial park, which will regulate the zone; and the 100 percent Chinese owned Eastern Industrial Park Ltd. Co., which invest in and operate the park. On the basis of their experience at home, Chinese developers expect host governments to support zone development actively; instead, they find that governments allocate land to developers and do little else. Chinese companies have found that promises of services like "one-stop shops" fail to materialize untill quite recently. The inexperience of some of the developers has been a contributing cause of uneven progress (World Bank Annual Manufacturing Report, 2015).

\subsection{Ethiopian Industrial Parks Characteristics and Key Challenges}

All the zones face some common challenges albeit at different degrees. Based on the field visits, concluded by the author throughout 2017, and from the report provided by the Ethiopian investment commission, ${ }^{43}$ the following major drawbacks are witnessed.

1) Legal and institutional framework, which is the foremost important challenge. The environmental standards, labor and technology transfer issues are not even taken seriously in annual regulatory plan of the industrial parks regulator existing in Bole-Lemi and East Industry Zone. Those issues are left for specific Ministries at Federal level which is almost impractical for them to regulate.

2) Infrastructure. This is an overall constraint for all the zones but at different degrees. Some of them have not completed the business plan and the feasibility study yet. For Ayka and Bole-Lemi parks the major infrastructure needs are on-site ones. All zones faces challenges in term of off-site roads, power but no potential investor has agreed or negotiated to build a power plant for the zone.

3) Environmental impact. All the zones have committed to comply with the environmental standards and minimize the environmental impact. So far zones haven't completed the environmental impact assessments. When the zones began to operate, the issue of managing wastes and pollution continued to be a challenge, especially for those zones with a high component of steel processing

${ }^{43}$ The research finding is also affirm/strengthens the report provided by the investment commission to the Ethiopian parliament, on January 2016, which is publicized through Ethiopian Reporter under

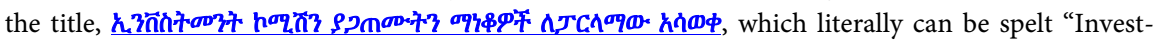
ment commission reported main investment drawbacks to the parliament" accessed from http://www.ethiopianreporter.com on 13 Jan 2016 (TC. 2 \$3 2008). 
and chemical sectors, such as the East industry zone and Hawassa Industrial Park large usage of textile chemicals.

4) Zone management and operational know-how \& experiences. Most of the zone developers, including the relevant government agencies, do not have the zone management and operational experiences,. In this regard, the East industry zone is relatively in a poor position-it has a Chinese zone as its minority stakeholder and hasn't conducted several workshops/study tours for the local partners to understand the Chinese/East Asian experiences in Industrial parks.

As shown in Appendix 3 of the respondents in each four industrial parks strongly disagree that the existing laws put focused and clear objectives. The same range of respondents strongly disagree that objectives are not sufficiently consulted with investors and nearby business and residents. As shown in Appendix 4 of the respondents in each four industrial parks strongly disagree that existing laws do not put clear criteria for location decisions and the location decision are not made in consultation with potential investors and nearby communities-SME's and residents. As shown in Appendix 5, 48\% - 52\% of the respondents in each four industrial parks strongly disagree that Clear, transparent and consistent procedure are set for land acquisition procedure. The same range of respondents in each four zones has also strongly disagreed that the existing laws made clear what kind of land/area is to be designated for industrial park development. As shown in Appendix 6,61\% - 65\% of the respondents in each four industrial parks strongly disagree that clear, transparent and consistent objectives are set for selecting investors. The same range of respondents in each four parks strongly disagree that the existing laws put clear criteria for selection of investors for Industrial parks development.

\section{Major Findings}

1) The industrial parks regulatory laws of the country fail to define and prioritize their specific objectives in line with the current stage of industrial parks development of the world. The transition and emerging market countries of Asia, Latin America and Africa have also tried to target their industrial parks regulations to:-encourage developing backward linkages (i.e., establishing a domestic support industry that provides locally produced goods and services for the free zone-based manufacturers), sought to create more backward linkages by extending many of the tax-free and duty-free incentives to local producers outside the free zones, encourage private sector participation in the establishment of industrial parks and facilitate an ongoing exchange with the local economy.

2) The industrial parks regulatory objectives of the country do not show a clear balance between static and dynamic benefits of industrial parks. The international experience also indicated that the major goals of regulations of industrial parks need to be creating backward and inward linkage with the local firms and economy and building the industry on sectors/activities of regional comparative advantage. The recent recommendation regarding industrial parks regulation is also towards further balancing between the objectives of attracting FDI, 
increasing foreign exchange and creating higher employment, on the one hand, and creating wider economic transformation.

3) In Ethiopia, the crucial location selection and demand identification and overall dimensioning are predominantly, if not exclusively, taken as "public issue" and a mandate of public entity. The location of the industrial parks is inserted into the GTP I and II without prior sufficient and independent consultation and demand driven market based feasibility study. The laws are silent on providing guiding principles and rules of location choice in developing industrial parks. Based on empirically developed theories on industrial Parks, location decision should separate political support from political objectives. The commercial case must be present. Although strong commitment from the government is needed, projects must be designed carefully on the basis of clear policy, strategic plans, feasibility study, environmental baseline study and sufficient consultation with stakeholders.

4) In Ethiopia, investor selection process is not well integrated into the law so as to provide the principles, criteria and incentives provided in selecting investors for industrial park developer, industrial park enterprise and industrial park operator. This will create two major obstacles: the selection process will be prone to qualify political affiliated companies for industrial parks and the investor selected will not deliver the dynamic benefits-backward and forward linkage. In fact, most successful zones that start with substantial FDI are eventually dominated by locally - based firms. This was the case, for example, in Malaysia and Korea.. We find some moderate share of local ownership in most countries, with substantial levels in Vietnam, Senegal, and Tanzania. In addition, the FDI should be closely linked to domestic enterprises and industrial clusters through partnership investment or supply chains or value chains. The investor selection process should play important roles in bringing new technologies continuous technology learning and upgrading, become centers of knowledge and technology generation, adaptation, diffusion, and innovation.

5) In Ethiopia, the authority responsible for industrial parks regulation is not well-defined, centralized having all the necessary powers and duties. The regulatory authority is shared between Ethiopian Investment Commission, Ethiopian Industrial Parks Development Corporation, Ethiopian Investment Board, Ministry of Industry, Ministry of Environment and Forest, Ministry of labor and Social Affairs. The regulation of environment, labor and technology transfer is shared between the ministries while the grievance handling and appellate power is shared between the commission and the board. International experience shows that the authority responsible for industrial parks regulation should be one very centralized, independent and empowered to regulate all of those regulatory issues shared by the above five organs. The international experience shows that regulator is managed by an executive board, which is overseen by a supervisory board composed of members from the public and private sectors. These members represent industrial park enterprises, which have a vested interest in developing infrastructure and utilities for the park. The executive board then 
meets with the supervisory board at the annual general meeting, where investors in the park are represented through a federation. This experience will help Ethiopia, as days goes by private developers of industrial parks is increasing (the Chinese, Egypt, Turkish IP) and their representation in board will make a conducive business environment and helps in making purely public interest based regulatory function separated from administrative tasks.

\subsection{Key Regulatory Success Factors and Lesson for Ethiopia}

The following key lessons could be taken for Ethiopia from the provided case studies of selected successful countries: Local producers selling into the industrial parks should obtain duty drawback on imported inputs (as an indirect exporter), putting them on a level playing field with foreign suppliers to the industrial parks; the local market restriction should be in place to protect against unfair competition, which is understandable given the size of the local industry and the substantial incentives available to park-based companies; the rules should put greater emphasis on private sector participation in zone development and also substantially alter the role of the authority by splitting its regulator function from its development and management role; the rules should set clear and objective criteria for site selection and mandatory feasibility studies to eliminate discretionary powers and erratic decision making; the rules should ensure that all zones are operated on commercial principles and the market to drive the price of services; the rules should allow the conversion of any zone into an IP with parameters fulfilled; the rules should open up the fiscal incentives of the IP program to export-oriented companies and real estate developers who invested in the physical infrastructure of industrial parks anywhere in the country; the rules should create more backward linkages by extending many of the tax-free and duty-free incentives to local producers outside the free zones; suppliers from the domestic economy to IP companies should be exempted from import duties on the raw materials used in this production. This allows them to at least be on equal footing with competitors supplying the zones from outside the country and Finally, the development of strong local clusters is acknowledged as making a significant contribution to the successful upgrading of FZ-based manufacturers by giving them access to competitively priced, world-class quality inputs; host governments, however, can create attractive conditions, facilitate contacts, and provide various direct or indirect incentives that make it cost-effective for foreign companies in SEZs to get supplies from local sources.

\subsection{The Objective of Regulation and Takeaway for Ethiopia}

Over the past 30 years, the focus of industrial parks regulation has progressively shifted toward achieving the dynamic contribution of zones to economic restructuring and their use as instruments to enhance competitiveness. Hence, the industrial parks law of the country should more specifically aim on dynamic benefits than outdated traditional static benefits. i.e. Foster and generate economic development by encouraging foreign investments; Aim to regulate loca- 
tion selection, establishment and management of industrial parks as an urbanization and industrialization planning tool; arrange establishment process, location selection, management, finance, and construction of industrial parks; encourage the establishment and development of industrial enterprises and upgrade labor and management skills through acquisition of advanced technology.

\subsection{Areas That Need Regulatory Frameworks and Takeaway for Ethiopia}

Based on empirically developed theories and experience of countries as illustrated above, industrial parks location decision should be guided by the following rules and principles: Although strong commitment from the government is needed, projects must be designed carefully on the basis of clear strategic plans, feasibility study and based on investors demand; Placing IP's away from urban and populated centers to encourage job creation and economic development in rural areas and to reduce the rural-urban migration; take advantage of location, trade preferences, and labor arbitrage to create large-scale employment and to support a transition away from reliance on natural resource sectors toward the development of a light manufacturing sector. Based on empirically developed theories and experiences of countries as illustrated above, industrial park investor selection process should be guided by the following rules and principles: Demand identification should not exclusively taken on by a public entity rather consultants are hired by the government for demand identification; The investor selection process should at least be conducted three months prior to the construction of the park and after investor demand is certified; foreign investors partnering with domestic and government public enterprises should be given special incentives to achieve the dynamic benefits of IP-technology transfer, skill development and long-lasting investment by the domestic investor after the foreign investor's return. Based on empirically developed theories and experiences of countries as illustrated above, industrial park land acquisition process should be guided by the following rules and principles: The land acquisition process should be shared by different actors-those decision makers, consultants, regional states and the firms investing in the park; location selection should be shared between state and center and land provision should be the explicit responsibility of state governments.

\subsection{Regulatory Organs and Takeaway for Ethiopia}

From the presented experience of countries and the peculiar features of the three models of industrial parks governance models, the following major lessons could be taken for Ethiopia in establishing a mix of statutory and corporation model. This will ensure the organ responsible for developing and administering industrial parks be market driven than political decision, profit-driven than loans/fund allocation, investor friendly, efficient in solving investors demand and to separate industrial park development from administration functions. In a mix of statutory body and a corporation model the statutory body protects the 
government's interests and administers the park. The corporation holds the land and develops the complex; land is rented to investors, generating sustainable income. A corporation is a profit-driven entity created to develop and administer an industrial complex so it could finance the park activities and better respond to client demands. The authority should be managed by an executive board, which is overseen by a supervisory board composed of members from the public and private sectors. These members represent industrial park enterprises, which have a vested interest in developing infrastructure and utilities for the park. The executive board then meets with the supervisory board at the annual general meeting, where investors in the park are represented through a federation.

\section{Conclusion}

The current industrial parks regulatory instruments of the country also have elements from the international experience. Those elements include the existence of special laws, definition of industrial parks, rational of their establishment, existence of regulatory objectives, establishment of regulatory organ and establishment of industrial park developer. A number of them are, however, incomplete, restrictive or inappropriate to the domestic situation and needs of the country. The establishment regulation of IPDC of Ethiopia is incomplete and ambiguous to classify the authority either in the three types of models of Arthur D. Little Governance models scenarios. While the corporation is established with a capital allotment, establishing it as a federal Public Enterprise and absence of a clear rule for the body designated for supervisory purpose makes it unclear. The supervisory body and its composition are not designated under the establishment regulation and are left for the government to assign as such. The industrial parks proclamation rules have inadequate rules on location choice, investor selection process, land acquisition process and in establishing independent, central and efficient grievance handling authority. The development and regulation of a country's industrial parks are a matter of regulatory determination and coordination between federal \& sates. It is important that a country possesses clear vision about the targets of its reforms; clearly defines, prioritizes and links between the objectives and instruments of its regulation; makes its reforms holistic as opposed to piecemeal; sequences its reforms clearly by taking into account both domestic and international context; and possesses strong determination in the pursuit and implementation of its reforms. The presence of dynamic domestic entrepreneurs/investors (in particular, the presence of a backward and inward linkages) is important for a country although small capacity of its economy and domestic investors. A country whose FDI is at very low level which needs to see the diversification of its investors and the creation of domestic and foreign investors partnership primarily as means to enhance domestic wider economic liberalization for long term domestic economic linkage and secondarily as means to facilitate foreign investment. It needs to put in place both proactive and reactive measures (that can encourage development and reduce risk) in the regulation of its industrial parks, institutions and services; and refine the regulatory 
regime through time purely based on business driven.

The following needs to be the major legal reform among others:

1) The industrial parks regulation need to include additional industrial park investor's licensing rules on its regulatory features such as: a simple licensing requirement for private developers and encouraging licensing requirement for foreign investors partnering with domestic investors, simple and encouraging requirement for at least one dynamic domestic investor to be present in each industrial parks and giving a legal personality and licensing to a common commercial association in the park established by all investors in a given park that organizes market information seminars and participates in large-scale trade fairs.

2) The establishment regulation of Industrial Parks Development Corporation (Regulation 326/2014) should establish the clear status of the corporation (whether it is a corporation with profit motive or a corporation with a board or a corporation accountable to the prime minister or a corporation accountable to the investment commission) rather than just mentioning the corporation as Federal Public Enterprise while at the same time just mentioning a body to be designated by government shall be supervisory body of the corporation. The establishment regulation should establish the Corporation in statutory and corporation governance model.

3) Industrial Parks regulation should add incentive rules to encourage forward and backward linkage such as: rules that qualifies local entrepreneurs around a park for unique incentives or extend existing investment law incentives to local companies supplying raw materials to IP investors; Add rules that obliges IP administrator provide technical assistance to local producers to work with the industry park investor; rules that extends additional incentives for foreign investors working with local producers for technology transfer and provision of raw materials and expressly give priority to foreign investors developing in joint ventures with local partners or domestic dynamic entrepreneurs.

4) The industrial parks law of the country should add the following rules to facilitate location selection to be transparent and business driven: rules that enable the corporation delegate actual implementation and focus on monitoring; oblige the industrial parks developer to decide on location after independent consultation, feasibility study and investor demand are conducted.; establish a consultant committee composed of government and leading domestic investors to provide their view on location decisions; oblige the developer assure that the location will closely link domestic enterprises and industrial clusters through supply chains or value chains.

5) The investor selection guiding principles \& rules should be added into the rules such as: expressly gives priority to foreign investors with higher technology knowledge capable of adaptation, diffusion, and innovation; and expressly gives priority to foreign investors partnering with dynamic domestic investors expressly to be licensed for investing in the park. 


\section{Acknowledgements}

The author wishes to thank Daniel Behailu (Dr.iur.) for his academic advice.

\section{Conflicts of Interest}

The author declares no conflict of interest regarding the publication of this paper.

\section{References}

Aggarwal, A. (2005). Performance of Export Processing Zones: A Comparative Analysis of India, Sri Lanka and Bangladesh, Indian Council for Research on International Relations.

Aggarwal, A. (2006). Special Economic Zones-Revisiting the Policy Debate. Economic and Political Weekly, November 4.

Aggarwal, A. (2010). Economic Impacts of SEZ: Theoretical Approaches and Analysis of Newly Notified SEZ in India. India: Department of Business Economics, University of Delhi.

Balasubramanyam, V. N. (1988). Export Processing Zones in Developing Countries: Theory and Empirical Evidence. In D. Greenaway (Ed.), Economic Development and International Trade (pp. 157-165). London: Macmillan.

https://doi.org/10.1007/978-1-349-19174-1_9

Brautigam, D., Farole, T., \& Tang, X. Y. (2010). China's Investment in African Special Economic Zones: Prospects, Challenges, and Opportunities. The World Bank.

Dinh, H. T., et al. (2012). Light Manufacturing in Africa: Targeted Policies to Enhance Private Investment and Create Jobs. Africa Development Forum Series. Agence Française de Développement and the World Bank.

https://doi.org/10.1596/978-0-8213-8961-4

Dommen, B., \& Dommen, E. (1999). Mauritius: The Roots of Success, a Retrospective Study, 1960-1993. Oxford, UK: James Currey.

Eifert, B., Gelb, A., \& Ramachandran, V. (2005). Business Environment and Comparative Advantage in Africa: Evidence from the Investment Climate Data. Center for Global Development Working Paper No. 56. https://doi.org/10.2139/ssrn.1112857

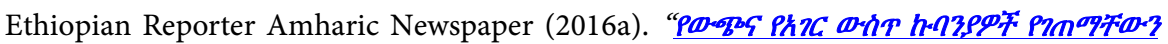

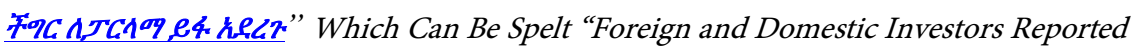
Drawbacks of Investment to the Parliament". https://www.ethiopianreporter.com

Ethiopian Reporter Amharic Newspaper (2016b). "AHm

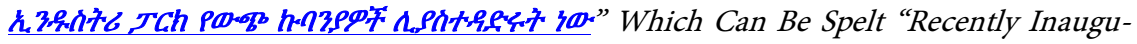
rated Hawassa Industry Park Is to Be Administered by Foreign Companies". https://www.ethiopianreporter.com

Farole, T. (2010). Second Best? Investment Climate and Performance in Africa's Special Economic Zones. World Bank Policy Research Working Paper No. 5447, Washington, DC: World Bank. https://doi.org/10.1596/1813-9450-5447

Farole, T. (2011). Special Economic Zones in Africa: Comparing Performance and Learning from Global Experiences. Washington, DC: World Bank. https://doi.org/10.1596/978-0-8213-8638-5

FDRE (2002). Industrial Development Strategy. Amharic Version, Addis Ababa: Mega Publishing Enterprise.

FDRE (2010). Growth and Transformation Plan 2010/2011-2014/2015. Volume I: Main 
Text, Addis Ababa: Ministry of Finance and Economic Development.

FDRE Regulation (2014a). Ethiopian Investment Board and Ethiopian Investment Commission Establishment Council of Ministers Regulation No. 313/2014.

FDRE Regulation (2014b). Industrial Parks Development Corporation Establishment Council of Ministers Regulation No. 326/201.

FIAS (Foreign Investment Advisory Service) (2008). Special Economic Zones. Performance, Lessons Learned, and Implications for Zone Development. Washington DC: World Bank.

Ganne, B., \& Lecler, Y. (2009). Asian Industrial Clusters, Global Competitiveness and New Policy Initiatives. Singapore: World Scientific Publishing Co. https://doi.org/10.1142/7374

Grunwald, J. (1991). Opportunity Missed: Mexico and Maquiladoras. Brookings Review, 9, 44-48. https://doi.org/10.2307/20080194

Hamada, K. (1974). An Economic Analysis of the Duty Free Zone. Journal of International Economics, 4, 225-241. https://doi.org/10.1016/0022-1996(74)90044-0

Healey, D. T. (1999). The Underlying Conditions of the Successful Generation of EPZ-Local Linkages: The Experience of the Republic of Korea. In R. L. Bolin (Ed.), Linking the Export Processing Zone to Local Industry (pp. 14). Arizona, USA: Flagstaff Institute.

ILO/UNCTC (1988). Economic and Social Effects of Multinational Enterprises in Export Processing Zones. Geneva: International Labor Organization.

Jenkins, M., Esquivel, G., \& Felipe, L. B. (1998). Export Processing Zones in Latin America. Development Discussion Paper No. 646, Harvard Institute for International Development.

Johansson, H., \& Nilsson, L. (1997). Export Processing Zones as Catalysts. World Development, 25, 2115-2128. https://doi.org/10.1016/S0305-750X(97)00103-4

Kaplinsky, R. (1993). Export Processing Zones in the Dominican Republic: Transforming Manufactures into Commodities. World Development, 21, 1851-1865.

https://doi.org/10.1016/0305-750X(93)90087-P

Little, A. D. (2014). Industrial Park Governance: The Vital Cog for Success. http://www.adl.com/

Mata, R. (1995). NAFTA Update: Steady U.S. Bilateral Trade Growth with Mexico Faces Mixed Prospects in 1995. Industry, Trade, and Technology Review, 1-4.

Mortimore, M. et al. (1995). Informe sobre la Competitividad Internacional en las Zonas Francas en la República Dominicana. Santiago de Chile: CEPAL.

Saleman, Y., \& Jordan, L. (2014). The Implementation of Industrial Parks: Some Lessons Learned in India. The World Bank Research Series.

Schrank, A. (2001). Export Processing Zones: Free Market Islands or Bridges to Structural Transformation? Development Policy Review, 19, 223-242. https://doi.org/10.1111/1467-7679.00132

Teutli, G. (1980). Maquiladoras in Mexico. In F. A. Rabbani (Ed.), Economic and Social Impacts of Export Processing Zones in Asia (pp. 6). Hong Kong: Update Publishing.

The World Bank (1992). Export Processing Zones. Policy and Research Series No. 20. Washington DC.

The World Bank (2012a). Learning from SEZs in India.

The World Bank (2012b). An Overview of Six Economic Zones in Nigeria: Challenges and Opportunities, Financial and Private Sector Development Department, Africa Re- 
gion.

The World Bank (2015). 4th Ethiopia Economic Update, Overcoming Constraints in the Manufacturing Sector. World Bank.

Türk, E. (2006). An Evaluation of Industrial Park Policy of Turkey: Ezmir as a Case Study. $42^{\text {nd }}$ IsoCaRP Congress.

Warr, P. G. (1989). Export Processing Zones: The Economics of Enclave Manufacturing. World Bank Research Observer, 4, 65-88. https://doi.org/10.1093/wbro/4.1.65

Watson, P. L. (2001). Export Processing Zones: Has Africa Missed the Boat? Not Yet! Africa Region Working Paper Series No. 17, Washington DC: World Bank.

Willmore, L. (1995). Export Processing Zones in the Dominican Republic: A Comment on Kaplinsky. World Development, 23, 529-535. https://doi.org/10.1016/0305-750X(94)00140-T

Zeng, Z. (2012). An Overview of Six Economic Zones in Nigeria: Challenges and Opportunities. World Bank Policy Note.

Zeng, Z. (2015). Global Experiences with Special Economic Zones Focus on China and Africa. The World Bank. https://doi.org/10.1596/1813-9450-7240

Zeng, Z. (2015). Global Experiences with Special Economic Zones: With a Focus on China and Africa. Addis Ababa: The World Bank Investing in Africa Forum. 